Arab World English Journal (AWEJ) Volume 12. Number1 March 2021

DOI: https://dx.doi.org/10.24093/awej/vol12no1.14

Pp.198-214

\title{
The Comparison between the Process-oriented Approach and the Product-oriented Approach in Teaching Writing \\ The Case of Moroccan EFL Students in Preparatory Classes for the Grandes Ecoles
}

\author{
Mariam Kadmiry \\ Faculty of Education, Mohammed V University \\ Rabat, Morocco \\ Email: mariam.kadmiry@gmail.com
}

Received: $12 / 24 / 2020$

Accepted: 2/8/2021

Published: 3/24/2021

\begin{abstract}
Writing is an important language skill, and learning to write is not an easy endeavour, especially for English as a foreign language (EFL) students. An effective EFL writing instruction, therefore, plays a significant role in helping EFL students deal with writing problems efficiently and approach writing tasks effectively. Based on this premise, the present study aims at investigating the effect of two alternative writing approaches, process and product, on Moroccan EFL students' writing performance to find out which of these approaches is more effective. It explores process writing instruction based on Hayes' (2012) recent model that responded to both critiques of the 1980-s original model of Flower and Hayes and to new ideas, which adds more layers to EFL writing research and instruction. To this end, the participants were divided into two groups, $\mathrm{A}$ and B, and they all took a writing pre-test before the treatment. For three months (two hours per week), group A students received academic argumentative writing instruction that was product-oriented, while group B students were taught academic argumentative writing based on Hayes' (2012) process writing model. After the treatment, all participants took a writing posttest. The analysis of the collected data revealed that group B participants showed a significant improvement in their compositions compared to their group A counterparts, which provides evidence that the process-oriented approach is more effective in enhancing EFL writing than the product-oriented approach. In the light of these findings, some pedagogical recommendations were suggested.

Keywords: academic argumentative writing, EFL writing instruction, Hayes' (2012) process writing model, Moroccan EFL students, process-oriented approach, product-oriented approach

Cite as: Kadmiry, M. (2021). The Comparison between the Process-oriented Approach and the Product-oriented Approach in Teaching Writing: The Case of Moroccan EFL Students in Preparatory Classes for the Grandes Ecoles Arab World English Journal, 12 (1) 198-214. DOI: https://dx.doi.org/10.24093/awej/vol12no1.14
\end{abstract}




\section{Introduction}

Writing plays an important role in our lives for many reasons. Socially speaking, writing is an integral part of today's modern life where emails, tweets, blog comments, Facebook posts, texts and other forms of written communication pervade (Graham et al., 2018). As for academic success, writing is an indispensable skill since it is the means by which information and data are gathered, refined, transmitted, exchanged and saved for future uses in any learning situation (Graham, Gillespie, \& McKeown, 2013; Harris, Graham, Brindle, \& Sandmel, 2009; Harris, Graham, Friedlander, \& Laud, 2013). In addition to that, most exams commonly depend on students' writing ability to test their knowledge and proficiency in foreign languages or other skills (Harmer, 2004). Writing is also a key requirement for professional growth especially in today's world that is heavily dependent on numerical data more than ever before (Hyland, 2003a), thereby making candidates with command of strong writing skills more favourable and benefitting from promotions and hiring decisions made by companies and corporations (Coker \& Lewis, 2008). Businesses spend large amounts of money on improving their employees' writing skills that contribute to the creation of a good corporate image, the building of strong customer relations, and the accomplishment of legal proceedings (Coker \& Lewis, 2008). Consequently, those who fail to acquire good writing skills encounter many barriers in their educational and professional life and are in a disadvantageous position in today's world (Harris et al., 2009; Harris et al., 2013).

This is quite true especially when writing in English, the language of international communication or the world language today, which is the case of Moroccan EFL students in preparatory classes for the grandes écoles. A strong mastery of English writing skills contributes to their high scores and rankings in both French and Moroccan exams, which puts them in a competitively advantageous position, increasing their chances of joining the best engineering or business schools and thus opening for them many horizons in their professional careers both here and abroad. Unfortunately, many preparatory classes Moroccan EFL students face problems in developing this skill, which may hinder them from realizing their educational and professional dreams. In fact, writing is the most challenging language skill to master for EFL learners (Richards \& Renandya, 2002) since it is demanding at all levels, cognitive, metacognitive and affective (Kellogg, 2008). Given this complexity of the writing skill and the challenges EFL students encounter in learning to write, the present researcher believes that an effective EFL writing instruction could enhance students' ability to overcome these challenges and approach writing tasks with more self-confidence.

The present study, therefore, aims at examining the effect of both the product and process approaches on the writing performance of preparatory classes EFL Moroccan students. It aims at comparing both approaches to find out which one yields more encouraging results in enhancing EFL students' writing performance. Process writing instruction has always been heavily criticized for its exclusive focus on writing processes. The present study, however, explores process writing instruction based on Hayes' (2012) recent model that responded to both critiques and to new ideas, which adds more layers to EFL writing research and instruction. To this end, the present study seeks answers to the following questions: 
1. To what extent does the product-oriented writing instruction enhance the writing performance of Moroccan EFL students?

2. To what extent does the process-oriented writing instruction improve the writing performance of Moroccan EFL students?

3. Does the product-oriented writing instruction develop the writing performance of Moroccan EFL students more than does the process-oriented instruction, or the opposite?

\section{Literature Review}

Product and process are two main approaches to second/foreign language writing instruction that have been broadly recognized. While the first one focuses on the written text, the second one gives more importance to the writer and the different stages of text creation.

\section{The Product-oriented Approach to Writing Instruction}

The traditional product approach perceives writing as a product of "combinations of lexical and syntactic forms and good writing as the demonstration of knowledge of these forms and of the rules used to create texts" (Hyland: 2003a, p. 4). Product-oriented teachers focus on formal accuracy and correctness at either a sentence- or paragraph-levels (Silva, 1990). They teach formal aspects of written texts such as vocabulary, grammar, cohesion, coherence, rhetorical organization, relevance of ideas to topic and so on and so forth. They regard writing "as an extension of grammar-a means of reinforcing language patterns through habit formation and testing learners' ability to produce well-formed sentences" (Hyland, 2003a, p. 3). To this end, student writers are required to imitate and adhere to specific models as White (1988) demonstrated in the following figure.

Study the model

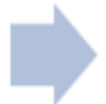

\section{Produce a parallel text}

Figure 1. A model-based approach to teaching writing (White, 1988, p. 5)

A model remains an important teaching tool by which students are taught the structure of good and coherent paragraphs, the different argument modes (such as cause and effect, comparison and contrast, classification, exemplification and so on and so forth) and discourse modes namely, description, narration, persuasion and exposition (Hyland, 2003a; Silva, 1990).

Since the product-oriented approach to teaching writing is form and language focused as well as model-based, this approach was put under heavy fire. First, it is true that grammatical structures and lexical patterns are crucial for SL/FL writers but "writing is obviously not only these things" (Hyland, 2003a, p. 6). Many FL students can form correct sentences and yet cannot write appropriate extended texts (Hyland, 2003a). Second, this approach overemphasizes the composed product and gives no insights into the route writers go through to develop that final product- that is to say the composing process (Flower \& Hayes, 1977). When emphasizing the product in teaching writing to our students, "all we have done, in fact, is to give them standards to judge the goodness or badness of their finished effort. We haven't really taught them how to make that effort" (Rohman, 1965, p.106).

This increasing dissatisfaction with the product-oriented approach to L2/FL writing led to the emergence of the process-oriented approach to writing instruction. It is noteworthy that 
despite all criticism directed toward the product writing approach, it is still widely used in FL writing instruction at different levels (Grabe \& Kaplan, 2014; Hyland, 2003a).

\section{The Process-oriented Approach to Writing Instruction}

Flower and Hayes' (1981) Cognitive Writing Model

Flower and Hayes' (1981) cognitive writing model is the most cited and most influential process model in the fields of education and psychology (Graham, 2006). According to Flower and Hayes (1981), writing involves the interaction between three important elements, namely the task environment, the writer's long-term memory, and the writing processes, as summarized in figure two.

Task environment refers to those variables that are "outside the writer's skin" (Flower \& Hayes, 1981, p. 369), specifically the rhetorical problem and the growing text. The rhetorical problem, or simply a school assignment, describes the topic, the rhetorical situation, and the audience, which constrain writers while writing and enable them solve the problem successfully and respond to the writing assignment efficiently. As writers attempt to solve the rhetorical problem by writing, the task environment's second component emerges and starts exerting a great influence on writers' decisions. It is the growing written text itself since "each word in the growing text determines and limits the choices of what can come next" (Flower \& Hayes, 1981, p. 371). To deal with the rhetorical problem in the light of the exigencies of the growing written text, writers rely on their long-term memory in which they have "stored knowledge, not only of the topic, but of the audience and of various writing plans" (Flower \& Hayes, 1981, p. 369).

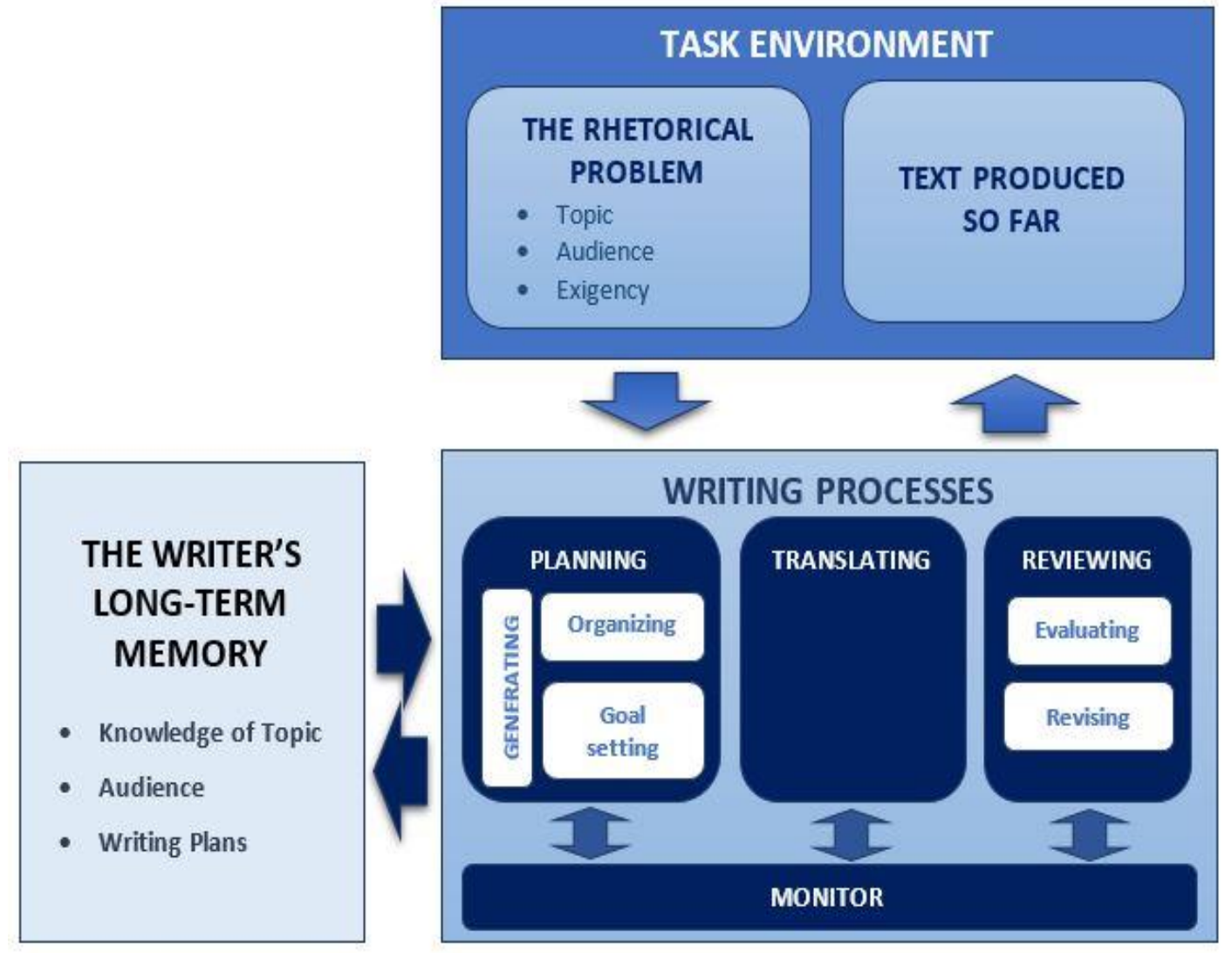

Figure 2. Flower and Hayes' Cognitive Process Model (Flower and Hayes, 1981, p. 370) 
The third element in Flower and Hayes' (1981) model is about writing processes of planning, translating, and reviewing, which are controlled by a monitor, the master process that enables writers track their current process and progress (Hayes, 2012). While planning writers try to guide themselves on how to proceed in their composing process, setting their goals and purposes, generating ideas and relevant information, and making a preliminary outline about the organization of their writing. This outline remains subject to constant change throughout the writing process when need arises. After putting an elementary plan, writers move to the second process, translating, in which they start tackling the first draft. In this process, they concentrate on getting ideas down on paper, without bothering themselves with the accuracy of expression. Finally, Reviewing takes place. In this process, writers rewrite their first drafts in order to refine their writing by making the necessary changes or modifications. They reconsider the objectives and purposes set previously at the planning stage and rethink about the topic and the audience (the rhetorical problem), paying attention to both fluency and accuracy. However, "We do not need to define "revision" as a unique stage in composing, but as thinking process that can occur at any time a writer chooses to evaluate or revise his text or his plans" (Flower \& Hayes, 1981, p. 376), leading him to constant planning and reconsideration of what he wants to say. Obviously, these writing processes do not occur in a linear fashion. Instead, they are characterized by simultaneity and interdependence (Flower \& Hayes, 1981; Harris et al., 2009).

$\mathrm{T} \quad$ his planning- translating- reviewing framework proposed by Flower and Hayes (1981) remained the most widely accepted and adopted process-writing model by second language (L2) writing teachers (Hyland, 2003a). Throughout all the stages of process writing classroom activities, the teacher's role is to guide students in the areas in which they need help, provide them with feedback, focus on what students do while writing, and may address students' weaknesses at the end of the writing session.

This process-oriented model has also come under fire, for its exclusive focus on writing processes. According to critics, this inductive method in teaching writing is not appropriate for all students (Horowitz, 1986). Teachers do not provide students with clear directives and an explicit instruction of the structure of the different target texts, leaving them on their own to discover appropriate forms while writing, drawing on their "growing experience of repetition" and on "suggestions in the margins of their drafts" (Hyland, 2003b, p. 19). After all, students are judged on their products regardless of the process they apply to reach them, and these products that are based on specific codes of a certain culture are more easily produced when the instructions of how to produce them are explicit (Delpit, 1988). FL learners, therefore, "find themselves held accountable for knowing a set of rules about which no one has ever directly informed them" (Delpit, 1988, p. 287), which may have serious consequences on their writing outcomes. As such, process writing approach fails to prepare learners for academic writing and, responding to the students rather than to the students' writing, it gives them a false impression of how academic writing is evaluated (Horowitz, 1986). Teaching students writing skills such as planning, revising, and editing is important but it is not enough.

To overcome these shortcomings, Flower and Hayes' (1981) process writing model was revised. After several years of empirical research and drawing on other writing researchers' work and theories, Hayes (2012) published a new version of the 1980s-writing model, in which he responded to both critiques of the original model and to new ideas. It is, in fact, "the latest in a 
sequence of writing models proposed by Hayes and his colleagues over more than 30 years" (Hayes \& Olinghouse, 2015, p. 481).

\section{Hayes' (2012) Writing Model}

This most recent model (Figure three) comprises three levels. The control level, as the name suggests, incorporates factors that form and guide the writing act. The process level comprises external and internal factors. It includes the inner cognitive processes involved in the writing act and the environmental components, both social and physical, that affect them. The resource level embraces functions that are important not only for writing but also for other human tasks (Hayes \& Olinghouse, 2015).

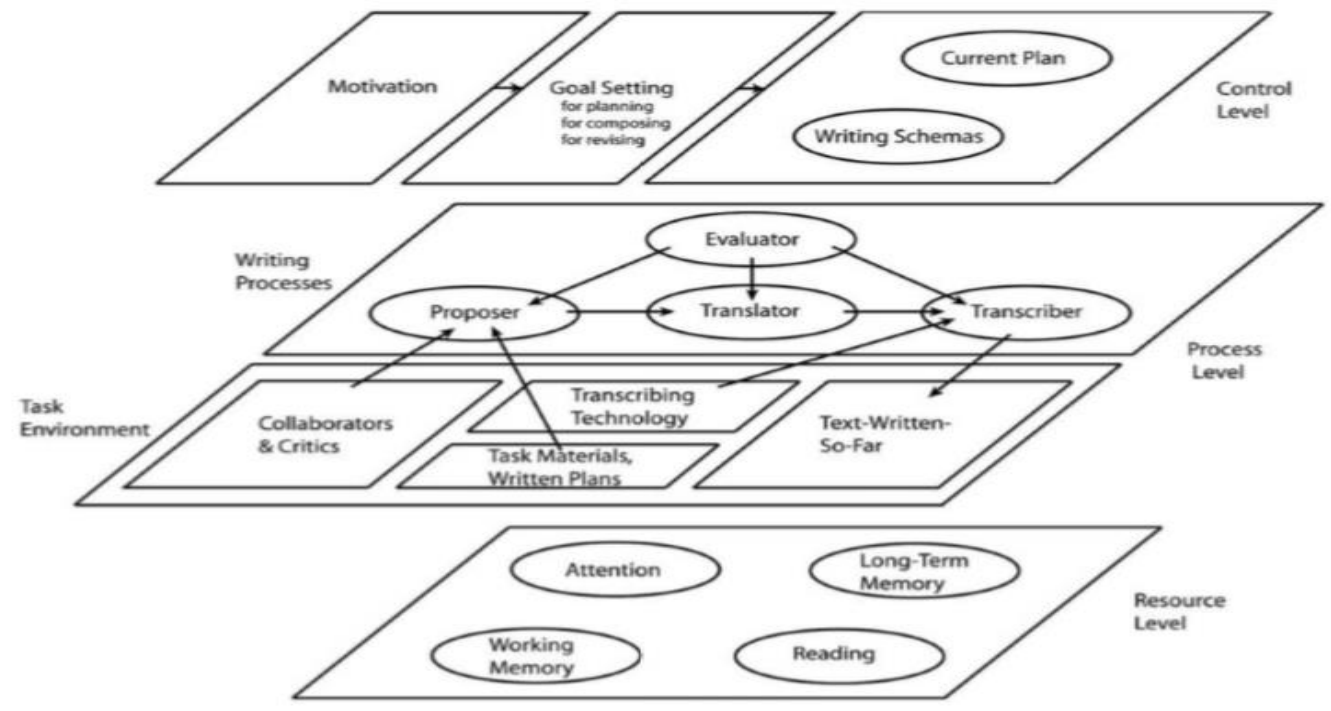

Figure 3. Hayes' (2012) writing model (Hayes, 2012, p. 371)

Hayes' (2012) process model, which is a new version of the 1980s-writing model, offers an accurate description of what goes on at each stage of the writing process and a full integration of cognitive, social, internal and external factors that influence writing. It is more comprehensive than the original model of the 80s. This model has brought new implications for EFL writing instruction through the process approach. First, unlike Flower and Hayes' (1981) old writing approach, Hayes' (2012) new model considers motivation as a requisite to writing development especially "through its influence on people's willingness to engage in writing” (Hayes, 2012, p. 372). Learners may not be motivated to write when they do not find a motive behind writing in their lives (Hayes \& Olinghouse, 2015), perceiving it as a classroom routine and an uninteresting activity (Boscolo, 2009). Here, the meaningfulness and attractiveness of classroom writing activities and tasks play an important role in the way students approach writing (Boscolo, 2009). Students may also have a low motivation towards writing when they "associate it with negative consequences" (Hayes \& Olinghouse, 2015, p. 482). For instance, they may feel afraid of harsh assessment especially if their linguistic and writing competencies are limited (Boscolo, 2009). Holding these beliefs and fears, students would avoid writing whenever possible thus a cycle can "begin in which lack of writing leads to lack of writing improvement, resulting in even less inclination to continue"'( Bruning \& Horn, 2000, p. 33). EFL writing teachers, therefore, should think about effective assessment methods that can reduce their learners' anxieties. 
In addition to motivation, writing schemas, which can be improved through explicit instruction (Hayes \& Olinghouse, 2015), constitute another important element in Hayes' (2012) new model and have a significant implication in teaching EFL writing to serve academic purposes. Writing teachers can begin their courses by building or improving their EFL students' writing schemas of different genres through explicit instruction of the properties of different written texts to help them tailor their writing according to the requirements of their academic contexts. As such, process-oriented courses, based on Hayes' (2012) new writing approach, can prepare EFL students for academic writing, hence overcome one of the shortcomings of Flower and Hayes' (1981) old model. In fact, Hayes' (2012) process writing model teaches students the two types of writing that Raimes (1991, p. 415 ) called for namely, "writing for learning" (i.e. prewriting, drafting, revising, and editing) and "writing for display" (i.e., writing to meet exam requirements).

Unlike Flower and Hayes' (1981) original process model in which social factors were absent, Hayes' (2012) revised model highlights the importance of collaborators and critiques in writing outcomes. Their contributions can be of great help especially when the writer's knowledge drawn from his or her memory is insufficient (Carver \& Scheier, 1991). In EFL writing classrooms, this may imply that while undertaking a writing task, students can draw on the knowledge and feedback of their peers as well as their teachers.

Furthermore, Hayes' (2012) process writing model stresses the importance of reading for good writing as well. In fact, writers resort to reading for several reasons. For example, as they compose, writers read and reread what they have written so far to continue writing since reading may be a source of inspiration for new ideas (Hayes \& Olinghouse, 2015). They need to "go back in order to move forward" (Zamel, 1982, p. 197). In addition to that, reading the text written so far serves revision and editing purposes (Hayes, Flower, Schriver, Stratman \& Carey, 1987). Similarly, writers repeatedly read documents written by others in order to use them as source materials in their productions (Alamargot, Dansac, Chesnet \& Fayol, 2007), which makes of reading a rich source of knowledge within a subject area (Hyland, 2003a). Consequently, EFL writing teachers should make use of this effective instructional tool, which is reading.

It is noteworthy to explain why planning and reviewing, which constitute major processes in addition to translating in Flower and Hayes' (1981) original writing model, have disappeared in Hayes' (2012) current model. "This may seem counterintuitive because we know that planning and revision happen" (Hayes, 2012, p. 375). However, there is a rationale behind this modification.

To achieve their writing goals, writers often make a plan before they start writing their texts. They may not need to write down their plans if they are clear, short and simple. Of course, such plans can be stored in memory and do not need to be transcribed (Hayes, 2012). Alternatively, if the plan is "complex", they may opt for creating "a written plan before writing the formal text" and in this case, it becomes "a separate text" and "part of the physical task environment for crafting the new text" (Hayes \& Olinghouse, 2015, pp. 482- 483). As such, a written plan should be conceived as a separate writing activity (Hayes, 2012). Likewise, writers who are engaged in formal writing activities like writing articles or school essays, revise their texts that will be read by other people "to meet standards for spelling, grammar, and other rules 
of good communication" (Hayes, 2012, p. 376). Revision here should also be considered as a separate writing activity since it is initiated by the detection of a problem, followed by planning a solution to that problem. This solution is translated into language that is transcribed into a new text, replacing the old one (Hayes, 2012). However, writers who are engaged in non-formal writing activities such as writing journals may not revise their texts since they are not going to be read by other people. In this case, "formal rules may be relaxed a bit" (Hayes, 2012, p. 376) and revision may be overlooked.

A number of studies compared the process writing approach to traditional writing instruction and found out that the process writing instruction resulted in a statistically significant improvement in students' overall performance (eg. Arici \& Kaldirim, 2015; Graham \& Sandmel, 2011; Mehr, 2017; Samsudin, 2016; Sarhady, 2015), hence the present researcher's interest in contributing yet another study to this line of research in the Moroccan EFL context. To the researcher's best knowledge, no study has attempted to investigate the effect of process-oriented writing instruction, based on Hayes's (2012) writing model, on EFL students' writing performance in Morocco, thereby the researcher's willingness to fill in the empirical gap in writing research and instruction in this context. It is in this sense that the present paper gains its significance.

\section{Methods}

\section{Participants}

Convenience sampling was used to select subjects who participated in the present study. In the 2019-2020 winter semester, the entire study group consisted of 64 participants (34 females, 30 males) who were first-year EFL students, studying maths and physics at a center of preparatory classes for the grandes écoles, Rabat- Morocco, where they were supposed to spend two years to be able to join one of the Moroccan or French engineering schools. Their age ranged from 17 to 19 years old, and they were admitted in preparatory classes for the grandes écoles due to their good ranking in the entrance selection based on their overall achievement results in the baccalaureate exam. Some of them have been studying English since they were in primary school. Those ones came from private schools. Others, on the other hand, who came from public schools, did not study English until they reached the last year of middle school. They formed two groups: group A contained 33 students and group B included 31 students.

\section{Instruments}

Data was collected based on two writing tests. One was administered before the experiment (pretest) and one after (post-test). Containing one writing prompt each, they aimed at assessing subjects' writing proficiency directly, asking them to actually produce a piece of argumentative writing on topics related to the themes they study in their English program. To increase their validity and reliability, both tests were evaluated by an advisory panel of three teachers of English, and then piloted before their submission to the participants and use for data collection in the present study.

\section{Procedures}

The present study adopted the quasi-experimental research design since a true-experiment was impossible in a school setting where classes were formed at the beginning of the year, thereby 
the unfeasibility of doing randomization of subjects into different groups. Two intact classes, therefore, participated in this study and the researcher implemented all experimental procedures.

\section{The Pre-testing Phase}

Prior to treatment, a one-hour session was devoted to the pre-test to measure participants' writing proficiency. All participants were assigned a writing task (the pre-writing test), asking them to write a four-paragraph argumentative essay. These essays were holistically graded, using a holistic grading scale that was adapted on the basis of the general rubrics proposed by Hyland (2003a). Holistic scoring was chosen over other scoring methods for its practicality, for its focus on global achievement and for the general impression it provides about the quality of students' writings (Hyland, 2003a), which best suits the present study's purpose. To improve the reliability of this holistic scoring, students' writing tests were rated by two assessors, which necessitated the assessment of Inter-rater reliability. The results revealed that there was a high Inter-rater reliability since the correlation coefficient was higher than .7. It was equal to .845 .

To ensure that the participants of both Groups had a similar writing proficiency in English, the independent samples t-test was conducted on the pre-test scores of both groups. The purpose of the independent samples t-test was to find out whether there were any significant differences between the proficiency levels of both groups. The results revealed that there were no significant differences in the levels of writing proficiency of the participants between group A $(M=10.44$, $\mathrm{SD}=1.47)$ and group $\mathrm{B}(\mathrm{M}=10.73, \mathrm{SD}=1.29) ; \mathrm{t}(62)=.829, \mathrm{p}=.410)$. Table one summarizes the results.

Table 1. Results of the independent samples t-test on the pre-test scores of groups A and B

\begin{tabular}{|l|l|l|l|l|l|l|}
\cline { 2 - 7 } \multicolumn{1}{c|}{} & Mean & Std. Deviation & Mean diff. & $\mathrm{t}$ & $\mathrm{df}$ & Sig.(2-tailed) \\
\hline Group A & 10.44 & 1.477 & .2872 & .829 & 62 & .410 \\
\hline Group B & 10.73 & 1.293 & & & & \\
\hline
\end{tabular}

\section{The Treatment Phase}

The treatment phase lasted three months (two hours per week) in which group A was taught writing based on the product approach while group B sat for writing sessions adopting the process-oriented approach.

Group A students received product-oriented writing instruction as described in figure one. In the first session, the teacher (the researcher) taught students the characteristics and features of the argumentative genre in terms of structure and content, as recommended by their educational program, through an analysis of an argumentative essay sample. Then, she suggested a writing topic and asked students to write argumentative essays based on the model text. In subsequent sessions, the participants were reminded of the properties of the argumentative genre and were asked to write argumentative essays on different topics. The teacher scored the essays after they were completed, and gave them back to the participants.

Group B students, on the other hand, received a process-oriented writing instruction by the same teacher, as shown in figure four. 
The first session of the intervention, the teacher (the researcher) began the writing course by building and improving students' writing schemas of the argumentative genre, as recommended by their educational program, through explicit instruction. In subsequent sessions, students were reminded of these characteristics and features and worked on a new writing topic.

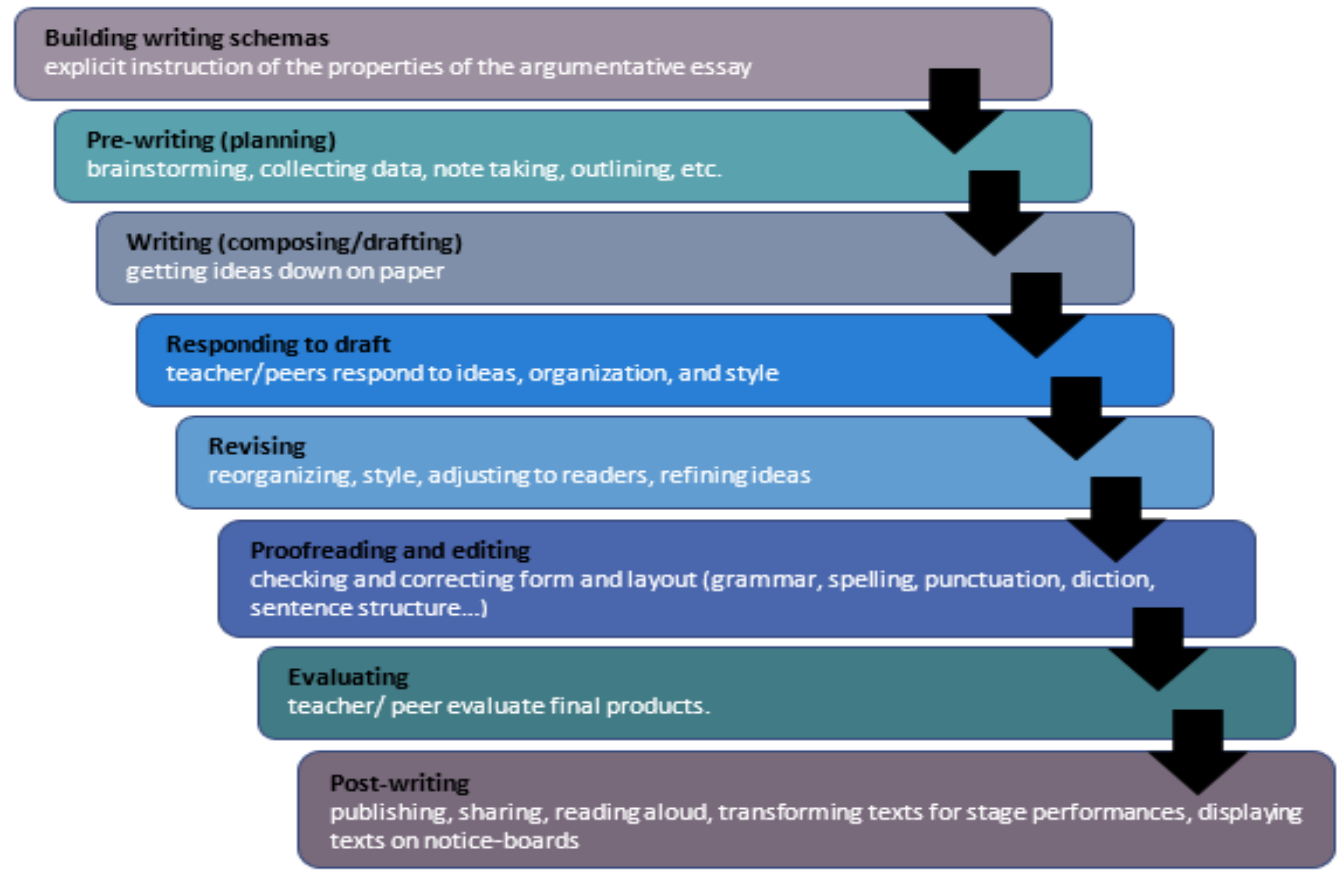

Figure 4. A process model of writing instruction (adapted from Hyland, 2003a, p. 11).

The planning stage incorporates goal-setting, idea generating and organizing. In setting goals, students were urged to define the rhetorical problem, or simply to read carefully the writing assignment, to understand the topic and to determine the rhetorical situation (argumentative essays) and the audience. Then, students were invited to generate ideas about the writing topic through group/ whole class brainstorming or semantic mapping and after that, they made a preliminary outline about the organization of their writing. Once sufficient ideas and information about the writing topic were gathered and an elementary plan was put at the planning stage, students moved to the next stage, drafting, in which they started tackling the first draft.

Once students produced the first draft and before proceeding to the revision stage, they exchanged their copies and expressed their reactions to each other's products in small groups or in pairs, with the aid of a checklist proposed by Seow (2002). They wrote their remarks in the margin, between sentence lines or at the end of the texts. The teacher (the researcher) supervised and participated in the responding process by (1) providing the necessary help to students to be able to react effectively and evaluate each other's writings successfully or by (2) expressing her opinion directly about students' writings.

In light of the feedback provided in the previous stage, students revised what they had produced. They were required to focus on the global content and the organization of ideas to ensure an effective communication between them and their readers and to avoid any misunderstanding or confusion. After revising their essays in terms of content and structure, 
students still needed to edit their drafts to make sure they were clear, concise, and error-free. At this stage, students were engaged in tidying up and refining their texts by making the necessary changes or modifications so that to be ready for evaluation. They edited their final drafts in terms of grammar, spelling, punctuation, diction, and sentence structure.

Once students felt satisfied with their final drafts after revising and editing them, they were invited to evaluate each other's essays in pairs or in groups. They had to examine relevance, development and organization of ideas, format or layout, grammar and structure, spelling and punctuation, appropriateness of vocabulary, and clarity of communication. They were issued the criteria for evaluation with a grading scale to assign a grade and were asked to write a short comment or evaluation at the end of the essays they evaluated to justify that grade. Of course the teacher (the researcher) supervised the evaluating process, provided support to students to do this task successfully, and intervened when there was a need.

The final stage in process writing instruction is post-writing that refers to "any classroom activity that the teacher and students can do with the completed pieces of writing" such as "publishing, sharing, reading aloud, transforming texts for stage performances, or merely displaying texts on notice-boards" (Seow, 2002, p. 319). In the present study, sharing, reading aloud and displaying texts on the classroom notice-board were the main and possible postwriting activities.

Throughout all the experimental procedures followed with group B, the teacher (the researcher) guided students in the areas in which they needed help, provided them with feedback throughout the writing act and focused on what students were doing while writing.

\section{The Post-testing Phase}

After the interventions were conducted, a one-hour session was devoted to post-testing to assess the impact, if any, of the treatments on students' writing performance. All participants were administered a post-writing test, asking them to write a four-paragraph argumentative essay. These essays were holistically graded, using the same holistic grading scale that was implemented in scoring participants' pre-writing tests. To improve the reliability of this holistic scoring, students' writing tests were rated by two assessors, which necessitated the assessment of Inter-rater reliability. The results revealed that there was an acceptable Inter-rater reliability since the correlation coefficient was higher than .7. It was equal to .767.

\section{Results}

To answer the first question, which measures the effect of the product-oriented writing instruction on the writing performance of group A students, the paired samples t-test was conducted to compare students' scores before and after treatment. Table two summarizes the results.

Table 2. Results of the paired samples t-test on pre-and post-test scores of group A

\begin{tabular}{|l|l|l|l|l|l|l|}
\cline { 2 - 7 } \multicolumn{1}{c|}{} & Mean & Std. Deviation & Mean diff. & $\mathrm{t}$ & df & Sig.(2-tailed) \\
\hline Pre-test & 10.44 & 1.47 & -0.38 & -1.749 & 30 & .091 \\
\hline Post-test & 10.83 & .86 & & & & \\
\hline
\end{tabular}


Table two shows that although the post-test scores of group A students ( $M=10.83, S D=.86)$ are higher than their pre-test scores ( $\mathrm{M}=10.44, \mathrm{SD}=1.47$ ), that difference remained non-significant; $\mathrm{t}(30)=-1.74, \mathrm{p}=.091$. These results suggest that the product-oriented approach did not significantly improve the writing performance of group A students. In other words, the productoriented approach does not have a significant effect on students' writing performance.

Likewise, to answer the second question, which measures the effect of the process-oriented writing instruction on the writing performance of group B students, the paired samples t-test was conducted to compare students' scores before and after treatment. Table three summarizes the results.

Table 3. Results of the paired samples t-test on pre-and post-test scores of group B

\begin{tabular}{|l|l|l|l|l|l|l|}
\cline { 2 - 7 } \multicolumn{1}{c|}{} & Mean & Std. Deviation & Mean diff. & $\mathrm{t}$ & $\mathrm{df}$ & Sig.(2-tailed) \\
\hline Pre-test & 10.73 & 1.29 & -1.09 & -6.939 & 32 & .000 \\
\hline Post-test & 11.82 & .86 & & & \\
\hline
\end{tabular}

As Table three displays, the post-test scores $(\mathrm{M}=11.82, \mathrm{SD}=.86)$ of group $\mathrm{B}$ participants were significantly higher than their pre-test scores $(M=10.73, S D=1.29) ; t(32)=-6.93, p=.000$. These results suggest that the process-oriented approach significantly improved the writing performance of group B participants. In other words, the process-oriented approach has a significant effect on students' writing performance.

To answer the third question, which compares the effect of both types of instruction on students' writing performance, the independent sample t-test was conducted. This statistical tool was used to compare the two groups in terms of their writing performance after the treatment and to see if there would be any significant differences in their post-test scores. The findings are summarized in table four.

Table 4. Results of the independent samples t-test on the post-test scores of groups $A$ and $B$

\begin{tabular}{|l|l|l|l|l|l|l|}
\cline { 2 - 7 } \multicolumn{1}{c|}{} & Mean & Std. Deviation & Mean diff. & $\mathrm{t}$ & $\mathrm{df}$ & Sig.(2-tailed) \\
\hline Group A & 10.83 & .86 & .9952 & 4.615 & 62 & .000 \\
\hline Group B & 11.82 & .86 & & & & \\
\hline
\end{tabular}

Table four reveals that after the treatment, group B participants $(\mathrm{M}=11.82, \mathrm{SD}=.86)$ had a significant higher score than group A students $(\mathrm{M}=10.83, \mathrm{SD}=.86) ; \mathrm{t}(62)=4.61, \mathrm{p}=.000$. These findings indicate that the process-oriented approach improved students' writing performance more than the product-oriented approach did. In other words, the process-oriented approach had a more significant effect than the product-oriented approach on students' writing performance.

\section{Discussion}

The present study investigated the effect of two alternative writing approaches namely, process and product, on Moroccan EFL students' writing performance and was an attempt to find out which of these approaches is more effective. The results indicated that the participants who received process-oriented writing instruction outperformed their counterparts who were taught writing through product-oriented approach. In other words, the study found that the process 
approach had a more significant effect than the product approach on students' writing performance. These findings are in line with previous research (eg. Arici \& Kaldirim, 2015; Graham \& Sandmel, 2011; Mehr, 2017; Samsudin, 2016; Sarhady, 2015). There are a number of factors that may have contributed to these findings.

The difference of focus and of instructional tools between product and process approaches are the first factors. While the product approach focuses solely on students' written products, the process approach, based on Hayes' (2012) writing model, focuses on both students' products and process. By building students' writing schemas of the argumentative genre, as recommended by their educational program through explicit instruction and by teaching students problem-solving writing strategies (i.e. planning, drafting, revising and editing), the process approach in the present study helped group B students know both how to benefit from the process as language learners and writers, and also how to tailor their products according to the requirements of their academic contexts (Raimes, 1991). This is why group B students outperformed group A students who were taught only the product, by providing them with a model of an argumentative essay to analyze and leaving them to their own devices to write a similar essay. As Flower and Hayes (1977) stated, product approach teachers help students study the product, but they "leave the process of writing up to inspiration" (p. 449). Group A students, therefore, were taught the product but not the process that could lead them to that product, which was not enough to achieve the desired results. In addition, the use of models as instructional tools enchains students' minds and kills their creativity (Sarhady, 2015). The process approach, however, engages students in recursive procedures demanding the use of planning, drafting, revising and editing strategies (Samsudin, 2016; Sarhady, 2015), thereby helping them hunt for ideas and thoughts, seek meaning, and refine their own writing step by step (Mehr, 2017), which encourages free, critical and creative thinking.

The second reason why Hayes' (2012) process approach had a more significant effect on students' writing performance than the traditional product approach in the present study is related to the time students received feedback. While group A students received feedback on their products till the end of the writing activity, simultaneously with evaluation, group B students were provided with feedback while writing in the responding stage, before being evaluated. Group B students, therefore, had the chance to revise and improve the quality of their products on the light of their teacher' and peers' remarks before they submitted the final versions of their products. Group A students, however, didn't have this opportunity since the feedback they received was late, after they handed their final products. This finding is consistent with Sarhady's (2015) and Mehr's (2017) studies in which the experimental groups' participants, who were provided with feedback from peers or the instructors, were able to improve their compositions and outperform their counterparts in the control groups who received product-based writing instruction where feedback was absent during the writing process. In fact, feedback while writing is one of the main factors that makes process-oriented instruction more rewarding and effective than product-oriented instruction (Seow, 2002). In other words, the process approach provides students with feedback throughout the composing process, which is constructive and helpful, whereas the product approach gives feedback after students finish writing, which is useless and ineffective. Feedback is important but what is more important is to give it at the right time. 
Another reason why Hayes' (2012) process approach had a more significant effect on students' writing performance than the product approach is related to what teachers and students do with the finished written products. This is what is referred to as post writing. Product approach teachers do not give importance to this stage and that is why in the present study, the teacher gave back group A students their papers after she corrected them. Process writing teachers, however, always suggest post-writing activities to recognize students' compositions as important and valuable, thereby motivating them for writing and prevent them from seeking excuses for not writing (Seow, 2002). In the present study, sharing, reading aloud and displaying texts on the classroom notice-board were the main and possible post-writing activities that the teacher tried with group B students who felt obliged, if not motivated, to write since their essays would be shared and displayed. Group A students, on the other hand, might not have been fully engaged in writing or might not have been motivated to write, perceiving maybe writing as a classroom routine and an uninteresting activity (Boscolo, 2009). In addition to post-writing activities, peer collaboration, personal responsibility, and a positive learning environment that are among the instructional components of the process approach are thought to enhance student writers' motivation (Graham \& Sandmel, 2011).

Last but not least, reading is among the factors that may have contributed to the present study's findings. Group B students were encouraged to read about the writing topic in advance in order to gather enough information. They were also advised to read what they had written if they felt stuck while writing, to be inspired and move forward. In addition to that, they obviously read and reread their products while revising and editing their essays. Group A students, on the other hand, were not urged neither to do some reading about the writing topic beforehand nor to read for inspiration, revision or editing purposes. Group B students, therefore, outperformed group A students since they were assisted with one of the effective tools that enhance writing at many levels. This result is in line with Samsudin's (2016) study in which the experimental group subjects, who were required to do a lot of reading while receiving process writing instruction, showed a significant improvement in their writing performance in terms of content, organization and mechanics. In fact, there is a strong relationship between reading and writing; reading improves writing by providing students "with the rhetorical and structural knowledge they need to develop, modify, and activate schemata which are invaluable when writing" (Hyland, 2003a, p. 17). In other words, reading offers "tacit knowledge of conventional features of written texts, including, grammar, vocabulary, organizational patterns, interactional devices, and so on" (Hyland, 2003a, p. 17). In addition to that, reading enriches students' topic knowledge that does not only affect the quality of students' written texts but it also relates to the amount of cognitive effort devoted to writing. In his study which examined the effect of topic knowledge on the amount of processing time and cognitive effort allocated to various writing processes, Kellogg (1987) found that writers with greater knowledge of the topic they wrote about allocated significantly less effort to the writing process than did low-knowledge writers. His finding supports the assumption that "The more an individual knows about a topic, the less effortful it might be to retrieve and use the relevant knowledge in preparing a written document" (Kellogg, 1987, p. 258). Group B students, therefore, outperformed group A students since reading may have unconsciously helped them get a sense for how writing should be done in terms of grammar and structure, learn new vocabulary and new ways of using that vocabulary, and gather enough information about the writing topic. 


\section{Conclusion}

Given the complexity of the writing skill and the challenges EFL students encounter in learning to write, the present study aimed at investigating the effect of two alternative writing approaches namely, process and product, on Moroccan EFL students' writing performance, an attempt to find out which of these approaches is more effective. The results indicated that the participants who were taught through process-oriented approach significantly outperformed their counterparts who were taught writing through product-oriented approach. In other words, the study found that the process-oriented approach had a more significant effect than the product-oriented approach on students' writing performance.

With reference to the related literature and the findings of the present research, it is advisable that EFL teachers adopt the process-oriented writing instruction in their classrooms. Though it is time demanding, it remains worth using. Planning activities such as brainstorming and outlining, drafting, responding, revising, editing, and evaluating are instructive problemsolving strategies that EFL writing teachers are urged to teach students to increase their selfreflection and evaluation of the writing process as well as their writing progress. Teachers are also advised to opt for process-oriented writing instruction since it provides a supportive learning environment where students and teachers interact around writing and collaborate with each other, which can drive students towards peak writing performance. It is also recommended that teachers think about interesting post-writing activities as a means to make classroom writing tasks more meaningful and students more motivated and willing to write.

In addition to these pedagogical recommendations for teaching EFL writing, the present study also suggests more longitudinal studies including larger samples from different educational levels for further research. Furthermore, additional research is needed to measure the potential motivational effect of process writing, using precise and reliable methods, since the present study estimated a positive motivational effect, considering a number of instructional constituents of the process approach, without measuring it.

\section{About the author}

Mariam Kadmiry is an EFL teacher in preparatory classes for the grandes écoles, RabatMorocco. She holds an MA in Applied Linguistics and TEFL. She is currently doing her doctoral studies in EFL writing instruction at the faculty of Education at Mohammed V University, Rabat- Morocco. Her areas of interests include Applied Linguistics, second/foreign language acquisition, EFL writing instruction, and TEFL issues. https://orcid.org/0000-0001-6305-8005

\section{References}

Alamargot, D., Dansac, C., Chesnet, D., \& Fayol, M. (2007). Parallel Processing before and after Pauses : A Combined Analysis of Graphomotor and Eye Movements during Procedural Text Production. In M. Torrance, D. Galbraith \& L. V. Waes, (eds.), Cognitive Factors in Writing (pp. 1-34). Dordrecht-Boston-London: Elsevier Sciences Publishers

Arici, A. F., \& Kaldirim, A. (2015). The Effect of the Process-based Writing Approach on Writing Success and Anxiety of Pre-service Teachers. The Anthropologist, 22(2), 318327. DOI: 10.1080/09720073.2015.11891883 
Boscolo, P. (2009). Engaging and Motivating Children to Write. In R. Beard, D. Myhill, J. Riley, \& M. Nystrand, (eds), The SAGE Handbook of Writing Development (pp. 300-312). London: SAGE Publications Ltd.

Bruning, R., \& Horn, C. (2000). Developing Motivation to Write. Educational Psychologist, 35(1), 25-37. http://dx.doi.org/10.1207/S15326985EP3501_4

Carver, C. S., \& Scheier, M. F. (1991). Self-regulation and the Self. In J. Strauss, \& G. R. Goethals, (eds.), The Self: Interdisciplinary Approaches (pp. 168-207). New York: Springer-Verlag.

Coker, D., \& Lewis, W. E. (2008). Beyond Writing Next: A Discussion of Writing Research and Instructional Uncertainty. Harvard Educational Review, 78(1), 231-251. https://doi.org/10.17763/haer.78.1.275qt3622200317h

Delpit, L. D. (1988). The Silenced Dialogue: Power and Pedagogy in Educating Other People's Children. Harvard Educational Review, 53(3), 280-299. https://doi.org/10.17763/haer.58.3.c43481778r528qw4

Flower, L. S., \& Hayes, J. R. (1977). Problem-Solving Strategies and the Writing Process. College English, 39(4), 449-461. https://doi.org/10.2307/375768

Flower, L., \& Hayes, J. R. (1981). A Cognitive Process Theory of Writing. College Composition and Communication, 32(4), 365-387. https://doi.org/10.2307/356600

Grabe, W., \& Kaplan, R. B. (2014). Theory and Practice of Writing: An Applied Linguistic Perspective. London \& New York: Routledge

Graham, S. (2006). Writing. In P. Alexander, \& P. Winne, (eds.), Handbook of Educational Psychology (pp. 457-478). Mahwah, NJ: Erlbaum.

Graham, S., Gillespie, A., \& McKeown, D. (2013). Writing: Importance, Development, and Instruction. Reading and Writing, 26(1), 1-15. DOI: 10.1007/s11145-012-9395-2

Graham, S. et al., (2018). Reading for Writing: A Meta-Analysis of the Impact of Reading Interventions on Writing. Review of Educational Research, 88(2), 243-284. DOI: 10.3102/0034654317746927

Graham, S., \& Sandmel, K. (2011). The Process Writing Approach: A Meta-Analysis. The Journal of Educational Research, 104(6), 396-407. DOI:10.1080/00220671.2010.488703

Harmer, J. (2004). How to Teach Writing. Essex: Pearson Longman.

Harris, K. R., Graham, S., Brindle, M., \& Sandmel, K. (2009). Metacognition and Children's Writing. In D. J. Hacker, J. Dunlosky, \& A. C. Graesser, (eds.), Handbook of Metacognition in Education (pp. 131-153). New York: Routledge.

Harris, K. R., Graham, S., Friedlander, B., \& Laud, L. (2013). Bring Powerful Writing Strategies into Your Classroom! Why and How. The Reading Teacher, 66(7), 538-542. DOI:10.1002/TRTR.1156

Hayes, J. R. (2012). Modeling and Remodeling Writing. Written Communication, 29(3), 369388.

Hayes, J. R., Flower, L. S., Schriver, K. A., Stratman, J. F., \& Carey, L. (1987). Cognitive Processes in Revision. In S. Rosenberg, (ed.), Advances in Applied Psycholinguistics: Reading, Writing, and Language Learning (Vol. 2, pp. 176-240). USA: Cambridge University Press.

Hayes, J. R., \& Olinghouse, N. G. (2015). Can Cognitive Writing Models inform the Design of the Common Core State Standards? The Elementary School Journal, 115(4), 480-497. Retrieved from https://www.learntechlib.org/p/161731/. 
Horowitz, D. (1986). Process, Not Product: Less Than Meets the Eye. TESOL Quarterly, 20(1), 141-144. DOI: $\underline{10.2307 / 3586397}$

Hyland. K. (2003a). Second Language Writing. USA: Cambridge University Press

Hyland, K. (2003b). Genre-Based Pedagogies: A Social Response to Process. Journal of Second Language Writing, 12(1), 17-29. DOI: 10.1016/S1060-3743(02)00124-8

Kellogg, R.T. (2008). Training Writing Skills: A Cognitive Developmental Perspective. Journal of Writing Research, 1(1), 1-26. DOI: 10.17239/jowr-2008.01.01.1

Kellogg, R. T. (1987). Effects of Topic Knowledge on the Allocation of Processing Time and Cognitive Effort to Writing Processes. Memory \& Cognition, 15(3), 256-266. Doi:10.3758/BF03197724.

Mehr, H. (2017). The Impact of Product and Process Approach on Iranian EFL learners' Writing Ability and their Attitudes toward Writing Skill. International Journal of English Linguistics, 7(2), 158-166. DOI: $10.5539 /$ ijel.v7n2p158

Raimes, A. (1991). Out of the Woods: Emerging Traditions in the Teaching of Writing. TESOL QUARTERLY, 25(3), 407-430. https://doi.org/10.2307/3586978

Richards, J. C., \& Renandya, W. A. (2002). Methodology in Language Teaching: An Anthology of Current Practice. USA: Cambridge University Press.

Rohman, D. G. (1965). Pre-Writing the Stage of Discovery in the Writing Process. College Composition and Communication, 16(2), 106-112. https://doi.org/10.2307/354885

Samsudin, Z. (2016). Comparing the Process Approach with the Product Approach in Teaching Academic Writing to First-year Undergraduates. AJELP: Asian Journal of English Language and Pedagogy, 4, 84-104. Retrieved from https://ejournal.upsi.edu.my/index.php/AJELP/article/view/1263

Sarhady, T. (2015). The Effect of Product/Process-Oriented Approach to Teaching and Learning Writing Skill on University Student Performances. International Journal of Language and Applied Linguistics, 1(2), 7-12.

Silva, T. (1990). Second Language Composition Instruction: Developments, Issues, and Directions. In B. Kroll, (ed.), Second Language Writing: Research Insights for the Classroom (pp. 11-23). Cambridge: Cambridge University Press.

Seow, A. (2002). The Writing Process and Process Writing. In J. C. Richards, \& W. A. Renandya, (eds.), Methodology in Language Teaching: An Anthology of Current Practice (pp. 315-320). USA: Cambridge University Press.

White, R. V. (1988). Academic Writing: Process and Product. In P. C. Robinson, (ed.), Academic Writing: Process and Product (pp. 4-16). Hong Kong: Modern English Publications and the British Council.

Zamel, V. (1982). Writing: The Process of Discovering Meaning. TESOL Quarterly, 16(2), 195209. https://doi.org/10.2307/3586792 